\title{
TRADE DIVERSION AND DECLINING TARIFFS: EVIDENCE FROM MERCOSUR ${ }^{1}$
}

\author{
Alok K. Bohara \\ University of New Mexico \\ Kishore Gawande ${ }^{2}$ \\ University of New Mexico and University of Texas, Austin \\ Pablo Sanguinetti \\ Universidad Torcuato Di Tella, Buenos Aires
}

Version: January 2001

\footnotetext{
${ }^{1}$ We thank Gil Merkx, the Latin American Institute at University of New Mexico, and the Packard Foundation for funding. We are grateful to Marcelo Olarreaga for generously providing an important part of the data. Helpful comments from seminar participants at the EIIT conference at CU, Boulder are acknowledged. Any remaining errors are our responsibility.

${ }^{2}$ Corresponding author. Visiting Scholar, Department of Economics, University of Texas at Austin, Austin, TX 78712. (Until January 2001). email: gawande@unm.edu.
} 


\begin{abstract}
This paper empirically examines the alternative posed by Richardson (1993) to the traditional view that trade integration may exacerbate inefficiencies through trade diversion. Richardson's hypothesis boldly predicts that trade diversion may actually cause tariffs to decline! The hypothesis is fundamentally attributable to the presence of a political component in the governments' objective functions. A cross-sectionally rich data-set on trade and tariffs from the Mercosur-pact countries, primarily Argentina, is used. The evidence yields surprising conclusions about the validity of the political economy construct in models of trade integration.
\end{abstract}




\section{Introduction}

The objective of this paper is to test an hypothesis from emerging political economy models of free trade agreements (FTAs). Introducing political economic features into the traditional analysis of trade agreements has surely enriched such models by imparting a real world flavor to them. This paper examines a political economy model due to Richardson (1993) that challenges the classical view that trade integration generally leads to trade diversion. The idea behind the theory is simple. If the level of tariff protection in an industry is due in part to the political power wielded by the industry, then as the political power if the industry diminishes with trade integration, so will the level of protection afforded the industry. Industries which experience trade diversion as the result of the FTA, where supply from the (less inefficient) FTApartner country replaces imports that previously originated in the (most efficient) rest of the world, are precisely the ones whose political power diminishes with the inception of an FTA. These industries are therefore most likely to see a reduction is tariffs on their imports from the rest of the world, as their political power is reduced. Eventually, these industries may experience true free trade as their external tariffs go to zero.

In the area of trade integration there has been little empirical work on the relevance of the new political economy models. An exception is Olarreaga and Soloaga (1998), who test the Grossman-Helpman (1995) model of the formations of FTAs. Since political economy is increasingly featured in the trade integration literature (e.g. Grossman and Helpman 1995, Krishna 1998, Maggi and Rodriguez-Clare 1999) a detailed empirical examination of the validity of the political economy construct is warranted. To this end, this paper investigates the counter-intuitive prediction from Richardson (1993) about trade diversion and tariffs under a free-trade agreement. 
The paper proceeds with an investigation of the hypothesis in the presence of no specific alternative, in the spirit of first-generation empirical work on the political economy of trade integration. It is hoped, this study will motivate more ambitious second-generation studies that formally compare political economy models with their more traditional counterparts.

A detailed cross-industry data set on intra-union and extra-union trade and tariffs from Mercosur over the period 1991-1996 is used in this study. ${ }^{3}$ The Mercosur free trade pact formed in 1991 among Argentina, Brazil, Paraguay and Uruguay is well suited for the purpose of examining Richardson's hypothesis. This study employs data on Argentinian tariffs before and after the trade agreement. Being the smaller of the two leading Mercosur countries (Brazil being the other), many of its industries faced the possibility of decline due to free trade with Brazil, a country twice its size in total output. This setting is apt for an examination of whether declining industries experienced increased or lowered protection.

The paper proceeds as follows. In Section 2 provides background information on Mercosur, including the nature of trade policy in the two major partner countries, Argentina and Brazil, before and after the formation of the trade agreement. In Section 3, Richardson's prediction is derived and its testing motivated. In section 4 the Mercosur data are described, and the empirical results presented. The results are interpreted in light of the theory. In section 5 concluding observations are offered.

\footnotetext{
${ }^{3}$ We are grateful to Marcelo Olarreaga for his generosity with important components of the data used in this study.
} 


\section{Background on Mercosur.}

The first article of the Treaty for the constitution of the South Common Market

(MERCOSUR) among Argentina, Brazil, Paraguay and Uruguay (Treaty of Asunción), signed in

1991, states that the agreement aims at achieving..."the free circulation of goods, services and

productive factors among the member countries, through the elimination of the tariff and non

tariff restrictions to the circulation of merchandises and of any other equivalent measure". ${ }^{4}$ The

institutional setting in charge to reach this objectives has been redefined in the Ouro Preto's

Protocol, signed in December of 1994. The main institutions of Mercosur are: the Council of the

Common Market (CCM), the Common Market Group (CMG) and the Mercosur Trade

Commission (MTC). ${ }^{5}$ The legislative bodies of the four countries have ratified this structure,

making MERCOSUR an institution of international law. Still, all bodies included in this structure

are of intergovernmental nature and not supra national and the decisions are taken by consensus.

${ }^{4}$ The Treaty also stipulates far-reaching objectives in terms of coordination of policies in other areas. In particular, policies applied in the following sectors: agriculture, industry, public taxes and expenditures, monetary rules, exchange rates, capital market, services, transports and communications. The coordination of policies in those areas should aim at assuring appropriate conditions of competition in the broadened economic space created by the integration process.

${ }^{5}$ The Council of the Common Market (CCM) is in charge of politically facilitating the integration process and for taking decisions to assure the execution of the objectives set in the Mercosur treaty. This body is comprised of ministers of Foreign Relations and of Economy of the four member countries. The Presidency of the CCM is for a duration of six months, and is rotated in alphabetical order. The Common Market Group (CMG) is the executive body of the Mercosur.. It is comprised of representatives from the Ministries of Foreign Relations, of Economy and of the Central Banks of the four States. A number of working sub-groups, specialized meetings and ad hoc groups assist the CMG. The Mercosur Trade Commission (MTC) is an intergovernmental body in charge of advising the CMG on trade matters, to oversee the evolution of common trade policies in the treaty. Mercosur as a regional integration scheme was notified to the GATT in February of 1992 through Brazil and in behalf of the Secretary of the Latin America Integration Association. GATT/WTO normative governs the relationships of the bloc with third countries. Within Mercosur, we have the Asunción Treaty, the Protocol of Ouro Preto and Brasilia, and the normative issued by the common bodies. Thus, the sources of law in MERCOSUR are (in decreasing order of importance): Treaty of Asunción, Protocol of Ouro Preto, decisions by CCM, resolutions of CMG, and directives of the MTC. 


\section{Tariffs}

The implementation of the Mercosur agreement implied the complete elimination of import tariffs affecting most trade among member countries. The process of tariff elimination was intended, through progressive, linear and automatic reductions in import taxes, to reach a zerotariff state by the end of 1994 . After an initial drop of $47 \%$ in the rates applied by each country to the imports coming from other members taken soon after the signing of the treaty in 1991 , successive reductions took place every six months so as to arrive at a zero tariff at the beginning of 1995. However, each state could maintain, transitorily and for a limited number of products, tariffs on imports from other Mercosur partners. ${ }^{6}$ Toward the end of 1994 these products were included in what was called the "Adaptation Regime" in order to lower their tariffs so that they would be completely eliminated by January 1, 1999 in the case of Argentina and Brazil, and by January 1, 2000 for Paraguay and Uruguay.

\section{Exceptions}

In addition to the general exceptions already indicated, the sugar and automotive sectors were not included in the intra-Mercosur trade liberalization due to significant divergence across member countries, especially Argentina and Brazil, in their national policies toward these sectors. An ad-hoc group for sugar and a technical committee for autos were created to ensure convergence in national policies. But in the interim, while the exchange of these products was subjected to a very complicated set of rules and restrictions, Argentina maintained quotas and

\footnotetext{
${ }^{6}$ Argentina had 223 tariff line items on this list. 57\% of the items were steel products, $19 \%$ were textiles, $11 \%$ were paper and $6 \%$ footwear. Brazil had only 29 such items, including wool products peaches in can, rubber factories and wines. Paraguay had 272 such tariff items, with the majority in textiles, some agricultural products, wood and steel. Finally, Uruguay had an extensive list with 1018 items, including textiles $(22 \%)$, chemical products and pharmaceuticals (16\%), and steel and electric machinery (8\%).
} 
prohibitions on sugar imports from its Mercosur partners. The Argentine position was that this was necessary due to the generous subsidies enjoyed by Brazilian producers from their government. For autos, a managed trade arrangement was put in place. It featured local content, concessional entry of parts, and a bilateral trade balance requirement.

\section{Common External Tariff}

Mercosur was to move to being a customs union by the year 2001. A common external tariff (CET) was temporarily agreed upon by 1995 , in order to give the countries sufficient time to converge to it. The average level of the CET was fixed approximately at $11 \%$, but it varied between 0 and $20 \%$ across industries. For the duration of this study it may be correctly presumed that Mercosur countries had considerable latitude on fixing their own external tariffs, just as in an FTA.

\section{Theory}

It is apt to begin with Viner's (1950) analysis of RTAs, since the concepts of trade creation and trade diversion developed by Viner have been central to much of the work in trade integration since. Viner analyzed the second-best situation of a three-country one-good case, where the highest price producer (least efficient) of a good, country $A$, has the opportunity to form a union with either the second highest price producer $B$, or the most efficient producer $C$. If $A$ 's tariffs is prohibitive so that it produces the good itself, regardless of partner, the union will increase welfare by enabling imports at a lower price. But if $A$ 's tariff is nondiscriminatory but not prohibitive before the union, so that it is importing from the least cost source $C$, then a free trade union with $B$, where both $A$ and $B$ shut out $C$ using a common external tariff on $B$, will be 
"trade diverting". $A$ will now import from $C$ at a higher than pre-union price. Of course, if both $A$ and $B$ were inefficiently producing the good before the union, their union would be trade creating as the less inefficient producer will capture the union market.

The Viner analysis pointed out the possibility of welfare losses from forming customs unions at a time when it was generally accepted that unions would increase world welfare and move to free trade. The trade diversion case is central to many recent political economy models of RTAs. Note that Viner's observation was not a positive one about whether customs unions would increase or decrease welfare, only that the relative strengths of trade creating and diverting forces should be considered while making such as prediction. Indeed, many empirical analyses of that day (see e.g. Lipsey, 1960) were finding in favor of customs unions primarily in Europe (e.g. Benelux and ECM).

How the recent political economy models of trade integration extend, modify or contradict some of the above conclusions are exemplified in the Richardson hypothesis. Notably, Richardson's is not an ad hoc proposition but one that emerges formally from a general equilibrium models.

\subsection{Richardson (1993): Trade Diversion and FTA tariffs}

Richardson (1993) considers a 3-country case where two small open economies, Home and a partner country, form a free trade area, excluding the third large country (rest of the world). Home produces $n$ goods, each using labor and sector-specific capital, plus a numeraire good that uses only labor. All good are produced with constant returns to scale technology. Home's government chooses tariffs to maximize a Stigler-Peltzman objective function that is a weighted 
sum of the welfare of labor and capital owners. Since their welfare is augmented by the redistribution of the tariff revenue to labor and capital owners (in some predetermined proportion), tariffs are endogenously determined in equilibrium. Richardson's insight, and the basis for the testable implication from his model, is as follows. Suppose the FTA leads to a sudden decrease in Home's tariff revenue, as the FTA partner country captures Home's market. This, in turn, leads Home's government to lower protection on imports from the rest of the world just enough to resume importing from the rest of the world and gain back some tariff revenue.

More precisely, consider Figure 1 (taken from Richardson), which depicts the small Home country, labeled country A, which forms a free trade agreement with country B. In Figure $1 \mathrm{ED}^{\mathrm{A}}$ is import demand in $\mathrm{A}(\mathrm{Home}), \mathrm{P}^{\mathrm{B}}$ is perfectly elastic supply of country $\mathrm{B}$ (FTA partner), and $\mathrm{P}^{\mathrm{C}}$ is perfectly elastic supply of the outside country $\mathrm{C}(\mathrm{ROW})$. The rest of the world, with perfectly elastic supply at the low price $\mathrm{P}^{\mathrm{C}}$, is the most efficient producer, while the potential FTA-partner country with perfectly elastic supply at the higher price $\mathrm{P}^{\mathrm{B}}$ is less efficient than the rest of the world, but more efficient than country A. In Viner's analysis, an FTA can have welfare reducing effects through trade diversion if, after an FTA is formed, the FTA-partner's price becomes lower than the pre-FTA tariff-ridden world price. In contrast, in Richardson's model, trade diversion is endogenously eliminated. In Figure $1, t^{0}$ is the pre-FTA nondiscriminatory specific tariff. When A enters into an FTA with B, it maintains the tariff on its external trade with C. B now fully supplies $\mathrm{A}$ along $\mathrm{P}^{\mathrm{B}}$. Compared with the pre-FTA equilibrium, the net welfare loss is area 2 (tariff revenue) minus area 3 (gain in consumer welfare). But the loss in area 2 can be avoided by simply switching to importing from $\mathrm{C}$ by lowering the tariff on $\mathrm{C}$ from $t^{0}$ to a level that brings $\mathrm{P}^{\mathrm{C}}$ $+t$ to a level lower than $\mathrm{P}^{\mathrm{B}}$, the partner-FTA price. The diversion eliminated, Home now imports 
from the rest of the world and enjoys additional tariff revenue. Maximizing the Stigler-Peltzman objective function leads Home to eliminate the trade diversion. The new equilibrium is still tariff ridden, but ceases to be if there is no domestic production of the good (i.e. when $\mathrm{ED}^{\mathrm{A}}$ is total demand in Home). If the Home sector vanishes, it has no incentive to levy any tariffs on the rest of the world, and as a result of the FTA, there is trade creation compared with the pre-FTA situation. Richardson's model thus yields the following testable prediction: ${ }^{7}$

\section{Hypothesis 1: External Tariffs (Richardson, 1993)}

External tariffs of a country joining a FTA should fall in declining industries, that is, those industries in which imports from the partner country initially increase.

Panagariya (2000) notes that the Richardson hypothesis is driven by the assumption that the supply curves of both, the rest of the world and the FTA partner country to which trade is initially diverted, are infinitely elastic. This implies that Home's imports come from either the rest of the world or the FTA partner, but not both. The hypothesis breaks down if the FTA partner's supply curve is upward sloping, for then the FTA partner cannot be eliminated as a source of supply and remains competitive at the margin. In the absence of any additional tariff revenue gain that would have been possible had trade with the rest of the world increased, there is no incentive to lower the external tariff.

Richardson's theory may be taken literally, in the sense that tariff revenue is the basis on

\footnotetext{
7 A second, equally important prediction from Richardson's model, that tariffs in FTA-countries should experience a larger decline than the common external tariffs in CU-countries, all else equal, is best tested using a cross-trade-bloc data. It is thus left open as a research issue.
} 
which the decision to increase or lower the tariff rests. ${ }^{8}$ Provided Home is small enough that the perfectly elastic supply assumption may be realistically maintained, Richardson's conclusion is robust to the use of other political economy constructs. Take, for example, the Findlay-Wellisz (1982) and the Grossman-Helpman (1994) political economy models. In both these models, lobbying by import competing industries leads to the endogenous determination of tariffs at a level higher than would be achieved if the government were to maximize pure welfare. The onset of a preferential trade agreement alters the incentives to lobby. If, due to trade diversion, Home's industry is now supplied by the FTA partner, it loses it's incentive to continue to lobby for tariffs on imports from the rest of the world. As a result, the tariff-ridden rest of the world price declines to a level just below the FTA partner price. Richardson's result therefore continues to hold under these different political economy formulations.

\section{Empirical Method and Data}

Brazil, the largest country, accounted for $65 \%$ of Mercosur output in 1991, the year of the pact, while Argentina, the next biggest country, accounted for $30 \%$. Uruguay and Paraguay, the smaller countries, accounted for the remainder. These smaller partners had trade-to-GDP ratios of over .35 in 1990, while Brazil and Argentina were relatively closed, with ratios of .11 (Brazil) and .15 (Argentina). Argentina, Uruguay and Paraguay fit the situation described by Richardson,

\footnotetext{
8 Tariffs have been a significant source of revenues in Mercosur countries. In 1992 import taxes in Argentina accounted for around 1\% of GDP or $7.4 \%$ of total tax revenue (IMF, 1998). In comparison with the $5.09 \%$ of total government revenue accounted by import taxes, income taxes contributed $6.5 \%$ of total government revenue. As the recession in 1995 lowered revenues, Argentina sought to raise tariff on imports from the U.S. The U.S. contested the tariff increase, successfully defending itself with the WTO. The 1995 actions demonstrate at least one occasion on which tariff revenue has been a motivating basis for trade policy in Argentina.
} 
of countries in which the free trade agreement could lead to the decline of industries in which imports from bigger partners replaced domestic output. In this paper we bring data from Argentina to bear on the theory, leaving the extension of this work to Uruguay and Paraguay as an open research issue.

Empirical analysis of the Richardson hypothesis is based on the regression model:

$$
\begin{array}{r}
\text { ExtTariff }_{i, t}=\beta_{0}+\beta_{1}(\text { IntImports/Value Added })_{i, t-1}+\beta_{2} \text { IntTariff }_{i, 96}+\delta_{i}+\delta_{t}+\epsilon_{i t} \\
t=92,93,96
\end{array}
$$

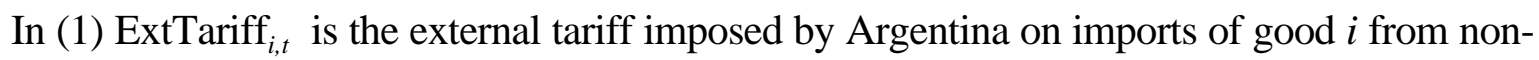
Mercosur partners at time $t$, and (IntImports/Value Added) ${ }_{i, t-1}$ is the Argentinian internal-importsto-value added ratio of good $i$ at time $t$-1, where internal imports refer to imports from Mercosur partners. $\delta_{i}$ measures fixed effects across the cross sections $i$ while $\delta_{t}$ measures time-fixed effects. Given the fixed effects and other regressors, $\epsilon_{i t}$ is a classically distributed error term. As indicated in Section 2, the Mercosur agreement featured "exclusions" that exempted some goods from the FTA. Goods in the excluded set maintained their nondiscriminatory tariffs on intra-Mercosur trade. A possible identification problem arises if exceptions are not adequately controlled for (as detailed in the next section). The variable IntTariff ${ }_{i, t}$, measuring the internal tariff imposed by Argentina on intra-Mercosur imports of good $i$ at time $t$, serves this purpose. For industries included in the FTA, IntTariff ${ }_{i, t}$ equals zero, but could be positive for excluded industries. IntTariff $_{i, t}$, therefore controls for exclusions. Due to the unavailability of internal tariff data for 1992 and 1993, the 1996 internal tariffs were used in their place. The 1996 internal tariffs are 
probably highly correlated with internal tariffs in the earlier years since no significant event took place in the intervening years to change them.

The validity of Richardson's hypothesis implies that $\beta_{1}<0$. In words, an industry's decline due to imports from an FTA partner is associated with a decline in its external tariffs. The increase in the internal-imports-to-value-added ratio variable captures the notion of a declining industry. ${ }^{9}$ As the industry declines, external tariffs that protect it are lowered in order to recapture part of the loss in tariff revenue by lowering tariffs enough that the rest of the world becomes competitive at the (lower) tariff-ridden price. That is the literal interpretation of the Richardson model. Essentially the same result holds in a model with lobbying by industries for tariffs. As the industry declines, so do the stakes from lobbying in that industry, as measured by the output-to-imports ratio (see e.g. Grossman and Helpman, 1994 on stakes from protection). As lobbying declines, so does protection, and hence $\beta_{1}<0$.

Parameter estimates of the linear model in (1) as well as the log-log model

$$
\operatorname{Ln}\left(\text { ExtTariff }_{i, t}\right)=\beta_{0}+\beta_{1} \operatorname{Ln}(\text { IntImports/Value Added })_{i, t-1}+\beta_{2} \operatorname{IntTariff}_{i, t}+\delta_{i}+\delta_{t}+\epsilon_{i t}
$$

are reported and discussed in the next section. Models (1) and (2) also provide quantitative estimates of the decline in external tariffs, if any, with the increase in internal imports.

The cross-sectional part of the data are organized at the 6-digit Harmonized System (HS) level of disaggregation. This level of detail was chosen over a more aggregate system of

9 While the theory is in terms of one-way trade, in the data, an increase in imports does not imply a decline of the industry. Quite the opposite, if, for example, the imports are intermediate goods imports for domestic assembly. Hence, the ratio of internal imports to value added provides the appropriate measure of industry decline. 
classification such as the 80-industry ISIC (rev. 2) 4-digit level, mainly because actual decisions about tariff rates are made a the HS level. The process of mixing heterogeneous micro-level information into aggregate data also masks, perhaps even overwhelms, information that may be relevant at the micro-level. For example, a tariff of, say, $10 \%$ may strongly affect imports of a HS 6-digit commodity, while imports of the industry which is made up of that and other HS 6-digit goods, may not be as strongly affected. The reason is, of course, that aggregation of goods with heterogeneous import elasticities mixes that information. Argentina's tariffs at the HS 6-digit level for the three years 1992, 1993 and 1996 were kindly provided by Marcelo Olarreaga. They are the basis for the more the aggregate ISIC 3-digit level study by Olarreaga and Soloaga (1998). The HS 6-digit cross-sections are pooled across these three years.

The examination of the Richardson hypothesis requires data on output, but the most detailed level at which output data are available is the ISIC (rev. 3) classification of 127 industries. The internal-imports-to-value-added ratio was thus computed at the ISIC (rev. 3) level, and then mapped into the HS 6-digit level using a standard conversion system. For each ISIC industry the ratio is computed as imports of Argentina from Brazil (imports from Brazil comprise over $95 \%$ of Argentina's total Mercosur imports) divided by value added. The ISIC level imports and output data were obtained from the Argentine Trade Commission (CNCE).

Of the full set of 5824 HS-6-digit goods, only manufactured products are considered. Taking into account restrictions imposed by data availability, the effective sample for the study is 11059 for the three years combined, or an average of 3688 HS 6-digit observations per year.

\section{External Tariffs in Declining Industries: Evidence}




\section{Econometric Issues}

When applying theory to the data, issues pertaining to the identification of the Richardson effect arise. The ideal "experiment" for testing the hypothesis is one which yields data that are informative about how the external tariff in a sector responds to the increase in internal imports from an FTA partner, all else held constant. In the Mercosur data, three identification issue must be solved. The first is the possible simultaneity between changes in the external tariff and internal imports for any good. ${ }^{10}$ An increase in Home's external tariff on a good should increase imports of the good from the FTA partner country, certainly if the partner is the more efficient producer of the good among the two union countries, but also if domestic production is unable to satisfy domestic demand. This reverse causality from the external tariff to internal imports therefore imparts a possibly strong bias in a direction opposite to that predicted by Richardson.

Lagging the variable IntImports/Value Added provides a solution to this problem. Results are reported for two types of lags, a one-year lag just as specified in (1) and (2), and another where, regardless of the year of the external tariff data (92, 93 or 96), IntImports/Value Added is computed for 1991, the year of the FTA. Since there is no theory to guide the econometric specification on the complex issue of the dynamics of how and when changes in the tariffs may occur as an industry declines, the two types of lags are used to investigate whether the results are robust across adjustment dynamics implies by those lags.

The second confounding effect is the presence of exceptioned sectors. If exceptioned sectors are not controlled for, an identification problem exists. In exceptioned sectors, Mercosur

${ }^{10}$ In any general equilibrium theory, nothing is really exogenous, and the effects transmit across goods. This is a difficult issue to resolve in this (or any) data, and we proceed under the assumption that those identification issues are mild and not as important as the within-sector effects described here. 
countries set tariffs on imports from their FTA partners, that is, the external tariffs were applied in a nondiscriminatory manner. In the such sectors, any increase in (external) tariffs would lower internal imports. This would result in a positive correlation between the change in external tariffs and internal imports, just as predicted by Richardson, but due to an entirely different mechanism. The variable IntTariff ${ }_{1996}$ is included in order to control for exceptioned sectors.

The third confounding effect is the results of the transitioning of external tariffs on some goods to the common external tariff (CET) as early as 1995-96. Even though partner countries were allowed to unilaterally impose external tariffs on most goods during the period of the analysis, this policy coexisted with the understanding that by 2001 their external tariffs would converge to the common external tariffs (CETs). The CET for each good had been agreed upon as early as 1995 in order to allow the Mercosur countries sufficient time to transition to the CET (in all but the exceptioned goods). To the extent that some countries started their adjustment to the CET early, it would introduce biases into measuring the Richardson effect. For example, if the CET in a sector had been set at a level higher than Home's nondiscriminatory tariff, and Home decided to impose this higher tariff immediately on rest of the world imports, then the Richardson mechanism is prematurely stopped short by the CET. Including those industries would, by causing high external tariffs to move positively with increased internal imports, and would impart a bias in a direction opposite to the Richardson effect. ${ }^{11}$ By the end of 1996, in Argentina's case, 42 of the 80 ISIC four-digit industries had transitioned to the CET. Of these cases, external tariffs had been raised in 31 and lowered in 11. If the Richardson hypothesis is validated with the

\footnotetext{
${ }^{11}$ If Home moved its external tariff in the direction of the CET at a lower than the pre-FTA tariff, in the data this would be reflected in lower external tariffs leading to trade diversion, again biasing the effect in the opposite direction to what is postulated by Richardson 's hypothesis:
} 
full sample, then the Richardson mechanism is actually strong enough to have overcome these opposing influences. In addition to results from the full sample, a smaller sample that excludes goods on which tariffs had already transitioned to the CET by 1996, is also used. This provides a check the robustness of the Richardson hypothesis, as well as produces estimates that are relatively free of the "CET bias".

\section{Empirical Analysis}

A background on Argentine tariff data is a useful prelude to the formal econometric analysis. In the immediate years preceding the Mercosur trade agreement, Argentina had completed a wide-reaching liberalization, including tariff liberalization, privatization of many public sector industries, and currency reform that fixed the Argentine peso to the U.S. dollar at par. By the time of the Mercosur agreement, because of its reforms, Argentina was already a low-tariff country in many industries relative to Brazil. Figure 2 depicts the distribution of its external tariffs across 4-digit ISIC (rev. 2) industries in 1996. At this level of aggregation, the distribution is not so different from the one in 1992, when the trade agreement went into effect. The maximum tariff rate applied in 1996 (and in 1992) was 30\%. In 1995, when the Mercosur countries agreed to the vector of common external tariffs to which all countries were to converge by 2000 , in many industries Argentina would converge to the CET from below. The importweighted tariff rate for Argentina was $13.5 \%$ in 1992 and $15.6 \%$ in 1996 . In contrast, its biggest trading partner Brazil would have to cut most of its tariffs in order to converge to the CET.

The message from Figure 2 is that, with tariffs already at their lowest level in two decades by 1992 , further decreases in the tariff would be politically costly for the government to achieve. 
The 1992-96 data therefore present a challenging testing grounds for a theory about tariff decreases. It is very likely that, given the already low tariff rates in 1992, industries which experienced further reductions in tariffs did so as the endogenous result of their declining political power. Any evidence about tariff decreases during the 1992-96 period and their association with an increasing market share of imports from Brazil would therefore provide strong support for Richardson's hypothesis.

The results presented in Table 1, are from the pooled time-series cross-section data using the models specified in (1) and (2). Cross sections at the HS 6-digit level for the external tariff data (ExtTariff) are pooled across 1992, 1993, and 1996. In the model specifications (1) and (2), for each cross section the issue variable IntImports/Value Added is lagged by a year. For example, in the 1992 cross section, IntImports/Value Added is from 1991. The first three columns of Table 1 contain estimates from the linear specification (1) and the last three columns contain estimates from the logged specification (2).

Consider the estimates from the linear model in column 1 of Table 1 . The statistically and economically significant estimate of -16.18 on the variable IntImports/Value Added affirms Richardson's hypothesis. It indicates that for every increase of .10 in the "market share" (as measured by share of value added) of imports from Brazil, Argentina's external tariff on imports from non-Mercosur partners decreased by an amount of $1.618 \%$. This is after controlling for cross sectional dummies at the two-digit HS level, two time dummies, and exceptions to the free trade agreement, measured by the variable Internal Tariff (the precisely measured positive estimate on Internal Tariff indicates that this adequately controls for exceptions to the otherwise free trade agreement). The decrease is precisely measured. Since the decline is measured with a 
lag on the external tariff, it appears to indicate a causal effect from an increase in internal imports to a decrease in external tariffs.

Is the magnitude of the decline economically significant? Given the already low levels of tariffs prevailing in Argentina in 1992, the estimated decline appears to be of an economically significant magnitude. It should be noted that a change on the order of .10 in the ratio IntImports/Value Added is not a trivial one. For goods that were already being imported from Brazil before the Mercosur agreement took effect, the change in IntImports/Value Added may not have been very high, implying that the estimated decline in their external tariff via the Richardson mechanism was not economically large. But for goods in which imports from Brazil were zero before the Mercosur agreement, but increased thereafter, the change could be possibly large, and theoretically equal to the ratio of total-imports-to-value-added if all of the rest of the world's imports were switched to Brazil. For such industries the estimated decrease in tariffs via Richardson's mechanism could be substantial.

A detailed inspection of the raw 6-digit level Harmonized System imports data indicated that in 1991 , of the 5824 possible HS 6-digit lines only $15.8 \%$ or 920 goods were imported from Brazil. In 1992, the year the Mercosur agreement took effect, 45\% or 2632 of the HS 6-digit goods were imported from Brazil, as imports from Brazil doubled in value from $\$ 1.5$ bn. To $\$ 3.3$ bn. However, there also seems to have been a regime change in the system of data keeping/classification during 1992, to which may be attributed at least part of the switch from zero to positive imports between 1991 and 1992 in many of the HS 6-digit categories. ${ }^{12}$ Since

12 This change in the data-keeping regime may be inferred from the fact that there is a similar switch in the number of HS 6-digit lines for which imports from the world increased from 1439 lines (24.7\% of all 6-digit lines) to 3902 (67\%) between 1991 and 1992. 
more detailed information about the nature of such a change is not available to us, it is difficult to make a precise statement about the extent to which the zero-to-positive switches were due to the data-keeping regime change. Nevertheless, there seem to have been a significant number of goods in which the imports from Brazil did change from zero to positive, and sometimes increased dramatically. For such goods, the estimated coefficient of -16.18 in the first column of Table 1 may imply a significant decline in their external tariffs as their political power declined.

If external tariffs are sticky then it is appropriate to include initial tariffs as a control variable. The second model thus includes tariffs in 1992 as a regressor. ${ }^{13}$ The model is estimated with only the 1993 and 1996 cross-sections, since the 1992 tariffs appear on the right-hand side. The inclusion of Tariff ${ }_{1992}$ substantially increases the fit on the model, as measured by the adjusted $R^{2}$. The large and precise estimate on Tariff ${ }_{1992}$ suggests that Argentina's 1993 and 1996 tariffs had a similar cross-sectional pattern as the 1992 tariffs. The effect of including base year tariffs is to lower the magnitude on the coefficient on the issue variable IntImports/Value Added to -8.517 . The coefficient is measured precisely. Again, the magnitude is economically significant for those goods which may have experienced a large increase in their internal-imports-to-valueadded ratio, indicating that Argentina's external tariff on imports from non-Mercosur partners decreased by an amount of $0.852 \%$ for every 0.10 increase in IntImports/Value Added.

The third column of Table 1 presents estimates from the model with full two-way effects. This is equivalent to including controls for all the 6-digit HS cross sections and two time dummies. The number of observations is 2800 per cross section pooled across the three years. ${ }^{14}$

\footnotetext{
${ }^{13}$ Ideally we would like to include tariffs from before 1992 but this data was not available to us.

14 This is lower than in the other models since, due to the small time dimension of the available data, a balanced panel was desired.
} 
The estimated coefficient on the issue variable IntImports/Value Added from the two-way fixed effects regression is smaller and less precisely measured than in the other regressions. The estimate is still negative, as predicted by the Richardson hypothesis. The full two-way fixed effects model may be overfitting the data, given the 2801 regressors in the model. The extra regressors do not add considerably to the explanatory power of the regression. In fact the second model produces the same adjusted $R^{2}$ as the much larger fixed-effects model. In terms of any formal model comparison criteria (though not reported here) such as the Akaike or Bayes information criteria which favor parsimony, the second model with 73 regressors is greatly preferred over the fixed effects model. Nevertheless, the fixed effects model is reported here as a check on whether the coefficient on the issue variable is robust to the myriad of industry-specific influences that are controlled via the full range of fixed effects.

The right half of Table 1 presents estimates of the elasticity of Argentina's external tariff with respect to the issue variable. The estimated coefficient in column 4 indicates that a doubling of the IntImports/Value Added ratio decreased Argentina's external tariff by $13.8 \%$. Including 1992 tariffs as a regressor (in column 5) lowers the estimated elasticity to 8.9\%. Both estimates are statistically significant and, given the already low tariffs, the estimated decreases are economically significant as well. This is especially true for goods in which imports were switched from the rest of the world to Brazil after the Mercosur agreement. As pointed out earlier, these good are most likely to register large increases in their internal-imports-to-value-added ratios. In the last column are reported estimates from the full fixed effects regression model. Unlike the linear fixed effects model, the logged model shows the largest effect among the three logged models. But just as was the case with the linear models, the model with Tariff ${ }_{1992}$ plus the HS 2- 
digit and time dummies is the preferred model among the three in terms of any information criterion that penalizes overfitting and rewards parsimony.

The dynamics of external tariff changes in response to change in the internal-imports-tovalue-added ratio is not known with any reasonable degree of certainty. The models in Table 1 imposed the restriction of a one-year lagged response of external tariffs to the internal-imports-tovalue-added ratio. The estimated models reported in Table 2 investigate the response of external tariffs to the internal-imports-to-value-added ratio in 1991. These models capture a different variety of dynamics in external tariffs than the models in Table 1, and provide complementary evidence.

The first two columns of estimates in Table 2 are from linear models. They largely affirm Richardson's hypothesis and corroborate the negative estimates on the issue variable presented earlier in Table 1. As in the earlier models, Internal Tariff, Tariff ${ }_{1992}$, the 2-digit HS dummies plus two time dummies perform adequately as control variables, allowing acceptable inferences to be made about the Richardson effect. The last two columns in Table 2 report estimates from the log models. The precisely estimated negative elasticity coefficients on the issue variable again confirm the presence of the Richardson effect in the Argentine data. While the elasticities are of smaller magnitudes relative to their counterparts in Table 1 , it should be noted that the changes in the ratio IntImports/Value Added are computed from the base year 1991. For example, the estimate in column 4 suggests that a quadrupling of this ratio since 1991 led, on average, to a $21 \%$ decrease in Argentina's external tariff. A quadrupling of the ratio since 1991 is quite possible for goods that were not imported or imported in small quantities from Brazil before the trade agreement, but for which Brazil became the main source of imports as trade was diverted to it 
after the trade agreement.

Table 3 explores the sensitivity of the Richardson effect to three different subsamples. The first deletes large values of IntImports/Value Added from the sample, and hence excludes possibly influential observations. The intent is to see whether the results are driven by a few extreme observations, or whether the results are unaffected by their deletion. The second deletes those HS 6-digit goods for which there was non-positive growth in internal imports. This is in line with Richardson's theory which applies to goods in which there is trade diversion, that is, goods in which the share of FTA-partner imports increase at the expense of imports from the rest of the world. The third deletes observations for which the external tariffs had converged to the common external tariff (CET) as early as 1996. Richardson's theory is one about free-trade areas, and does not address the complications of bargaining for the CET among members of a customs union. Deleting goods for which the external tariffs were determined not by the declining political strength of industries but rather by other factors determining the CET (such as relative bargaining strength) may make for a "purer" FTA sample, and provide a more ideal testing ground for Richardson's theory.

Table 3 presents the results from the sensitivity analysis of the linear model with all three cross sections, that is, Model 1 in Tables 1 and 2, are reported in Table 3. The sensitivity analysis of the linear model with Tariff ${ }_{1992}$ included as a regressor (Model 2 in Tables 1 and 2) and the logged models (Models 3 and 4 in Tables 1 and 2) provide the same qualitative picture, and are not reported here in the interest of brevity. ${ }^{15}$ Quite surprisingly, the Richardson effect is confirmed across the board. Its robustness to the three different sub-samples is striking. Neither

15 Those results are available from the authors. 
is it the case that the Richardson effect is diminished in any of the three sub-samples relative to the estimates from the full sample (reported in Tables 1 and 2). In fact, the Richardson effect comes out stronger in some of the subsamples. For example, when the logged model (not reported) is estimated with the "pure FTA" subsample $(N=2516)$, it yields an estimated elasticity of nearly $30 \%$ which is twice as large as the estimate from the full sample.

Results from the sub-sample with extreme values of IntImports/Value Added deleted indicates that the estimated effect is not driven by a few influential observations, but rather represents information contained in the broader sample. In the full sample, industries that did not experience trade diversion provide a "control group" with which to compare the "focus group", that is, industries that did experience trade diversion. This is one test of the presence of the Richardson effect, which was confirmed by the results in Table 1. With the sample restricted to only the trade diversion cases, the second and fifth columns of results in Table 3 empirically confirm a variation on the Richardson effect: the greater the trade diversion, the greater the decline in the external tariff. Finally, the "pure FTA" sub-sample (third and sixth columns of results in Table 3) indicate that the results from the full sample are not the result of external tariffs converging to the CET, but may be ascribed to the declining political power of industries weakened by the Mercosur trade agreement. If anything, the full sample actually underestimates the impact of this effect.

\section{Conclusion}

Political economy models in trade and other areas of economics are motivated by the notion that in the real world governments maximize something other than public welfare. Their 
purported aim of explaining real-world outcomes better than models based on pure welfare maximization makes them natural candidates for empirical testing. In this paper a political economy model of trade integration in Richardson (1993) is subject to an empirical examination. The main feature of this model is its counter-intuitive prediction that the diversion of trade from the rest of the world to the less efficient FTA-partner, that initially occurs as trade barriers are removed on trade between FTA partners but maintained on the rest of the world, will endogenously be lowered. The reason is that the initial tariffs are politically driven, and the result of maximization by the government of an objective function that includes tariff revenue. Hence, positive tariffs on some or all imports are optimal. But as imports in certain industries from the rest of the world are replaced by imports from the FTA-partner, tariff revenue in those industries also declines. As a result, these industries are no longer "politically influential", and their tariffs decline in the new equilibrium. Hence, the initial trade diversion is lowered or eliminated endogenously. If its prediction is true, then the model makes the case for free trade agreements, an issue that is quite controversial among policymakers and academics.

This prediction is empirically investigated using trade and tariff data from Argentina over the period 1991-96. Argentina was the second-biggest partner (Brazil being the biggest) to the Mercosur trade agreement, signed in 1991, among the four South American countries of Brazil, Argentina, Uruguay and Paraguay. A data set assembled at the 6-digit Harmonized System level of detail is used to examine whether the increasing penetration of imports from Brazil and the resultant "decline" of industries in Argentina led, via the Richardson mechanism, to the lowering of external tariffs in these industries. The results provide a strong affirmation of the Richardson hypothesis. The estimate from a preferred model specification indicates that a $100 \%$ increase in 
the ratio of internal imports (from Brazil) to value added leads to a lowering of the external tariff by around $9 \%$. Across the set of model specifications and sub-samples for which those models are estimated, this estimate ranges between 5\% and 30\%. In industries where imports from Brazil were zero or very low before the Mercosur agreement, but were subsequently diverted to Brazil, the increase in the ratio of internal imports to value added may be many-fold. The estimates indicate that in those cases the trade diversion would indeed lead to a substantial decline in their external tariffs. The prediction from the Richardson model is shown to be robust to a variety of model specifications, as well as well-motivated sub-samples. This paper has taken the first step towards the larger goal of testing political economy models of trade integration. The next step is to formally discriminate between (theoretically well-founded) hypotheses from that literature with their counterparts from models based on pure welfare maximization. 


\section{References}

Bond, E. W., Syropoulos, C. , and L. A. Winters. "Deepening of Regional Integration and Multilateral Trade Agreements." 1999. Manuscript.

Cadot, O., J. de Melo, and M. Olarreaga. "Regional Integration and Lobbying for Tariffs Against Non-Members", International Economic Review, 1999, 40, pp. 635-657.

CNCE Annual Report, 2000 (Comicion Nacional de Comercio Internacional Informe Anual, Buenos Aires, Argentina, 2000)

Ethier, W. J. "Regionalism in a Multilateral World." Journal of Political Economy, 1998, 106, pp. 1214-1245.

Findlay R. and S. Wellisz. "Endogenous Tariffs, the Political Economy of Trade Restrictions, and Welfare." In J. N. Bhagwati, ed. Import Competition and Response, Chicago: University of Chicago, 1982.

Gawande, K., and U. Bandyopadhyay. "Is Protection for Sale? A Test of the Grossman-Helpman Theory of Endogenous Protection." Forthcoming in Review of Economics and Statistics, 1999.

Goldberg, P. and G. Maggi, "Protection for Sale: An Empirical Investigation", American Economic Review, December 1999, 89, pp. 1135-1155.

Grossman, G. M. and Helpman, E. "The Politics of Free-Trade Agreements." American Economic Review, September 1995, 85(4), pp. 667-690.

Grossman, G. M. and Helpman, E. "Protection for Sale.” American Economic Review, September 1994, 84(4), pp. 833-850.

IMF, “Argentina: Recent Economic Developments.” IMF Staff Country Report No. 98/38, 1998.

Johnson, H. G. "An Economic Theory of Protectionism, Tariff Bargaining, and the Formation of Customs Unions." Journal of Political Economy, August 1960, 68, pp. 327-345.

Krishna, P. "Regionalism and Multilateralism: A Political Economy Approach." Quarterly Journal of Economics, 1998, 113, pp. 227-251.

Lipsey, R. "The Theory of Customs Unions: A General Survey." Economic Journal, 1960, pp. 496-513.

Long, N.V. and N. Vousden "Protectionist Responses and Declining Industries." Journal of 
International Economics, 1991, 30, pp.87-103.

Maggi, G. and A. Rodriguez-Clare. "The Value of Trade Agreements in the Presence of Political Pressure.” Journal of Political Economy, 1998,1 06, pp. 574-601.

Nogues, J. J., and R. Quintanilla "Latin America's Integration and the Multilateral Trading System.” In J. De Melo and A. Panagariya, eds. New Dimensions in Regional Integration. Cambridge: Cambridge University Press, 1993.

Olarreaga M., I. Soloaga., and L. A. Winters. “What's Behind Mercosur's CET?” Manusript, 1999.

Olarreaga M. and I. Soloaga. "Endogenous Tariff Formation: The Case of Mercosur." World Bank Economic Review 1998, 12, pp. 297-320.

Panagariya, A. "Preferential Trade Liberalization: The Traditional Theory and New Developments." Journal of Economic Literature, June 2000, 38, pp. 287-331.

Richardson, M. "Endogenous Protection and Trade Diversion." Journal of International Economics, May 1993, 34(3-4), pp. 309-324.

Viner, J. The Customs Union Issue. New York: Carnegie Endowment for International Peace, 1950. 
Table 1: Declining Industries and Tariffs in Argentina. Post-Mercosur Cross-section at HS 6-digits, pooled across three periods ${ }^{a}$

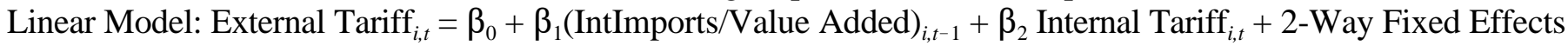
Log-Log Model: $\ln \left(\right.$ External Tariff $\left._{i, t}\right)=\beta_{0}+\beta_{1} \ln (\text { IntImports/Value Added })_{i, t-1}+\beta_{2}$ Internal Tariff $_{i, t}+2$-Way Fixed Effects

\begin{tabular}{|c|c|c|c|c|c|c|}
\hline & \multicolumn{3}{|c|}{ Linear Models } & \multicolumn{3}{|c|}{ Log-Log Models } \\
\hline & 1 & 2 & 3 & 4 & 5 & 6 \\
\hline $\begin{array}{l}\text { (Internal Imports/ } \\
\text { Value Added) })_{t-1}\end{array}$ & $\begin{array}{l}-16.18 * * \\
(22.48)\end{array}$ & $\begin{array}{l}-8.517 * * \\
(12.73)\end{array}$ & $\begin{array}{c}-1.872 * \\
(1.526)\end{array}$ & - & - & - \\
\hline $\begin{array}{l}\ln (\text { Internal Imports/ } \\
\text { Value Added })_{t-1}\end{array}$ & - & - & - & $\begin{array}{l}-.138^{* *} \\
(10.27)\end{array}$ & $\begin{array}{l}-0.089 * * \\
(6.036)\end{array}$ & $\begin{array}{l}-0.170 * * \\
(5.458)\end{array}$ \\
\hline Internal Tariff ${ }_{t}$ & $\begin{array}{l}.283 * * \\
(23.69)\end{array}$ & $\begin{array}{l}0.294 * * \\
(24.75)\end{array}$ & $f$ & $\begin{array}{l}0.024 * * \\
(7.038)\end{array}$ & $\begin{array}{l}0.019 * * \\
(7.380)\end{array}$ & $f$ \\
\hline Tariff $_{1992}$ & - & $\begin{array}{l}0.305 * * \\
(36.01)\end{array}$ & $f$ & - & $\begin{array}{l}0.046 * * \\
(25.54)\end{array}$ & $f$ \\
\hline CS and TS Dummies ${ }^{b}$ & YES & YES & - & YES & YES & - \\
\hline 2-Way Fixed Effects ${ }^{c}$ & - & - & YES & - & - & YES \\
\hline$N$ & 11059 & $7371^{d}$ & $8400^{e}$ & 11059 & $7371^{d}$ & $8400^{e}$ \\
\hline$k$ & 73 & 73 & 2801 & 73 & 73 & 2801 \\
\hline Adjusted $R^{2}$ & 0.472 & 0.609 & 0.608 & 0.307 & 0.457 & 0.394 \\
\hline
\end{tabular}

Notes: $* *$ indicates statistical significance at $5 \%$, and $*$ at $10 \%$ of single-tailed tests . Absolute $t$-values in parentheses. ${ }^{a}$ External tariff data at 6-digit Harmonized System (HS) level pooled across 1992, 1993, and 1996. ${ }^{b}$ Seventy crosssection (CS) dummies at 2-digit HS level, plus two time-series (TS) dummies. ${ }^{c}$ Fixed effects model with full set of CS and TS dummies. ${ }^{d}$ Since 1992 Tariffs are controlled for, data pooled across 1993 and 1996 cross sections only. ${ }^{e}$ Models with full set of fixed effects with balanced panel (3 TS obs. per CS group). Number of fixed effects was too large with the full sample for the model to be estimated. The number of fixed effects was reduced by discarding HS 6-digit groups for which internal imports in all three years were zero. ${ }^{f}$ Fixed effects are collinear with the variable (variable is redundant given fixed effects). 
Table 2: Declining Industries and Tariffs in Argentina. Post-Mercosur Same models in Table $\mathbf{1}$ but with the issue variable IntImports/Value Added from 1991

\begin{tabular}{|c|c|c|c|c|}
\hline & \multicolumn{2}{|c|}{ Linear Models } & \multicolumn{2}{|c|}{ Log-Log Models } \\
\hline & 1 & 2 & 3 & 4 \\
\hline $\begin{array}{l}\text { (Internal Imports/ } \\
\text { Value Added) }\end{array}$ & $\begin{array}{l}-22.41 * * \\
(19.58)\end{array}$ & $\begin{array}{l}-5.998 * * \\
(5.129)\end{array}$ & - & - \\
\hline $\begin{array}{l}\ln (\text { Internal Imports/ } \\
\text { Value Added })_{1991}\end{array}$ & - & - & $\begin{array}{c}-0.085^{* *} \\
(6.797)\end{array}$ & $\begin{array}{l}-.053 * * \\
(2.712)\end{array}$ \\
\hline Internal Tariff ${ }_{t}$ & $\begin{array}{l}0.280^{* * *} \\
(23.24)\end{array}$ & $\begin{array}{l}0.290^{* *} \\
(24.16)\end{array}$ & $\begin{array}{l}0.018^{* *} \\
(14.17)\end{array}$ & $\begin{array}{l}0.018^{* *} \\
(7.120)\end{array}$ \\
\hline Tariff $_{1992}$ & - & $\begin{array}{l}0.324 * * \\
(38.21)\end{array}$ & - & $\begin{array}{l}0.048 * * \\
(26.63)\end{array}$ \\
\hline CS and TS Dummies ${ }^{b}$ & YES & YES & YES & YES \\
\hline$N$ & 11059 & 7371 & 11059 & 7371 \\
\hline$k$ & 73 & 73 & 73 & 73 \\
\hline Adjusted $R^{2}$ & 0.467 & 0.602 & 0.303 & 0.455 \\
\hline
\end{tabular}

Notes: $* *$ indicates statistical significance at $5 \%$ and $*$ at $10 \%$. Absolute $t$-values in parentheses. See Notes to Table $\mathbf{1}$. 
Table 3: Sensitivity Analysis of Parameter Estimates in Tables 1 and 2

\begin{tabular}{|c|c|c|c|c|c|c|}
\hline & \multicolumn{3}{|c|}{ Model 1 in Table 1} & \multicolumn{3}{|c|}{ Model 1 in Table 2} \\
\hline & $\begin{array}{l}\text { Outliers/ } \\
\text { Influential }^{a}\end{array}$ & $\begin{array}{l}\text { IntImport } \\
\text { Growth }>0^{b}\end{array}$ & $\begin{array}{l}\text { ExtTariff } \\
\neq \text { CET }^{c}\end{array}$ & $\begin{array}{c}\text { Outliers/ } \\
\text { Influential }^{a}\end{array}$ & $\begin{array}{l}\text { IntImport } \\
\text { Growth }>0^{b}\end{array}$ & $\begin{array}{l}\text { ExtTariff } \\
\neq \text { CET }^{c}\end{array}$ \\
\hline $\begin{array}{l}\text { (Internal Imports/ } \\
\text { Value Added) })_{t-1}\end{array}$ & $\begin{array}{c}-18.32 * \\
(15.79)\end{array}$ & $\begin{array}{l}-18.55^{* *} \\
(20.24)\end{array}$ & $\begin{array}{l}-17.25 * * \\
(11.51)\end{array}$ & $\begin{array}{l}-23.84 * * \\
(14.53)\end{array}$ & $\begin{array}{l}-22.21 * * \\
(19.32)\end{array}$ & $\begin{array}{l}-22.05^{* *} \\
(10.31)\end{array}$ \\
\hline Internal Tariff $t_{t}$ & $\begin{array}{l}0.281^{* *} \\
(21.84)\end{array}$ & $\begin{array}{l}0.258^{* *} \\
(17.29)\end{array}$ & $\begin{array}{l}0.222 * * \\
(9.268)\end{array}$ & $\begin{array}{l}0.279 * * \\
(23.40)\end{array}$ & $\begin{array}{l}0.280^{* *} \\
(23.28)\end{array}$ & $\begin{array}{l}0.219 * * \\
(9.629)\end{array}$ \\
\hline CS and TS Dummies & YES & YES & YES & YES & YES & YES \\
\hline$N$ & 10297 & 8616 & 2516 & 10822 & 10892 & 2516 \\
\hline$k$ & 65 & 65 & 24 & 65 & 65 & 27 \\
\hline Adjusted $R^{2}$ & 0.479 & 0.465 & 0.341 & 0.475 & 0.468 & 0.338 \\
\hline
\end{tabular}

Notes: $* *$ indicates statistical significance at $5 \%$ and $*$ at $10 \%$. Absolute $t$-values in parentheses.

${ }^{a}$ Large values of (IntImports/Value Added) dropped.

${ }^{b}$ Only sample with positive growth in Internal Imports (between years $t-1$ and $t$ for Table 1 model and between years $t$ and 1991 for Table 2 model) considered.

${ }^{c}$ Observations with external tariff in 1996 equal to common external tariff (proposed in 1995) dropped to obtain "pure FTA" sample. 


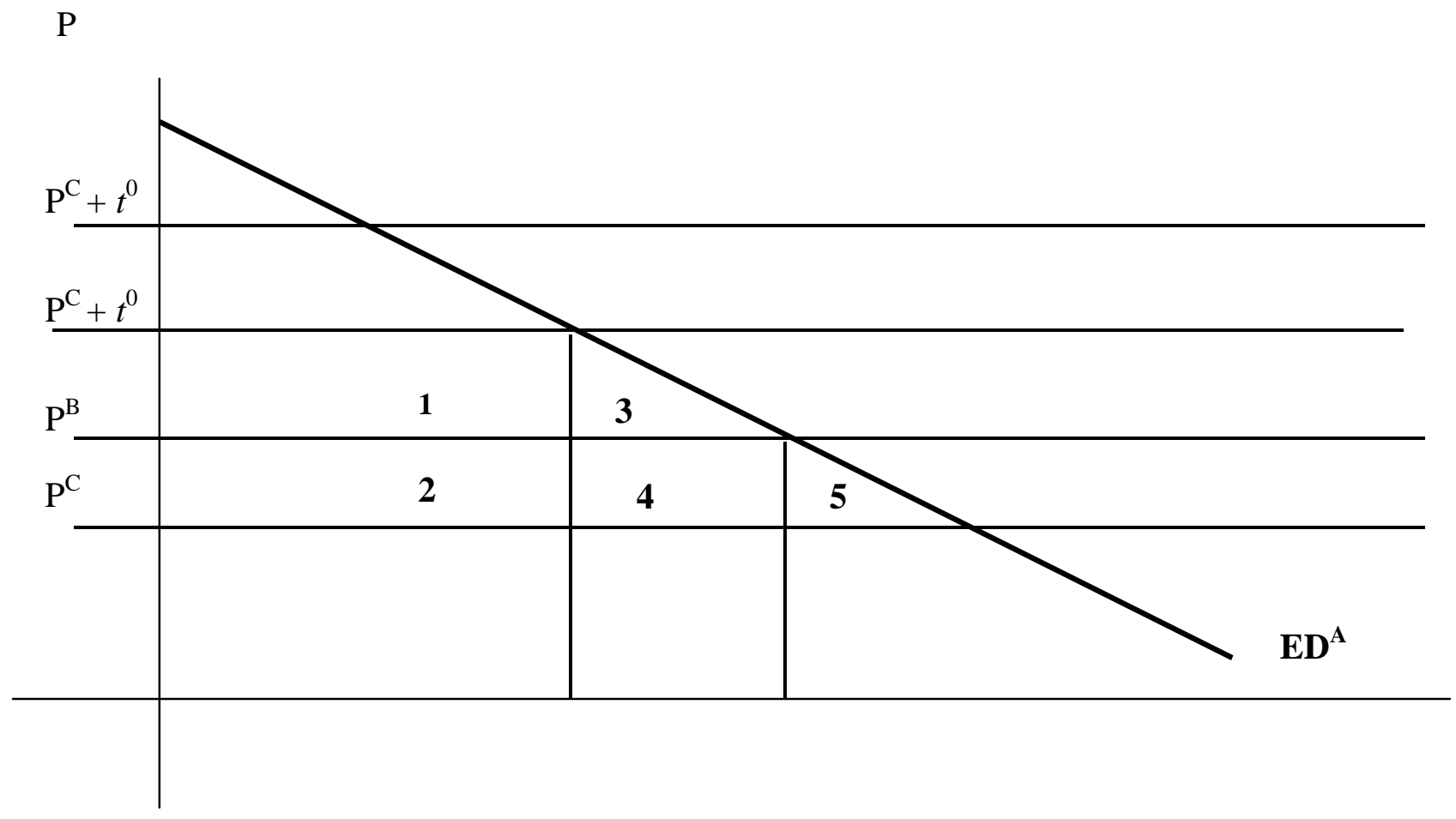

Figure 1: Richardson (1993): Trade diversion endogenously disappears.

$\mathrm{ED}^{\mathrm{A}}$ is import in $\mathrm{A}$ (Home), $\mathrm{P}^{\mathrm{B}}$ is perfectly elastic supply of country $\mathrm{B}$ (FTA partner), and $\mathrm{P}^{\mathrm{C}}$ is perfectly elastic supply of the outside country $\mathrm{C}(\mathrm{ROW}) . t^{0}$ is the pre-FTA nondiscriminatory specific tariff. With an FTA, A maintains the tariff in a discriminatory manner against C. B now fully supplies A along $\mathrm{P}^{\mathrm{B}}$. Compared with the pre-FTA equilibrium, the net welfare loss is area 2 (tariff revenue) minus area 3 (gain in consumer welfare). But the loss in area 2 can be avoided by simply switching to importing from $\mathrm{C}$ by lowering the tariff on $\mathrm{C}$ from $t^{0}$ to a level that brings $\mathrm{P}^{\mathrm{C}}+t$ to a level lower than $\mathrm{P}^{\mathrm{B}}$. In maximizing the Stigler-Peltzman objective function, Home's government is induced to do precisely that, eliminating trade diversion. The new equilibrium is still tariff ridden, but ceases to be if there is no domestic production of the good (i.e. when $\mathrm{ED}^{\mathrm{A}}$ is total demand in Home). 
Figure 2: Argentina's External Tariffs (\%) in 1996

ISIC (rev. 2) 4-digit industries

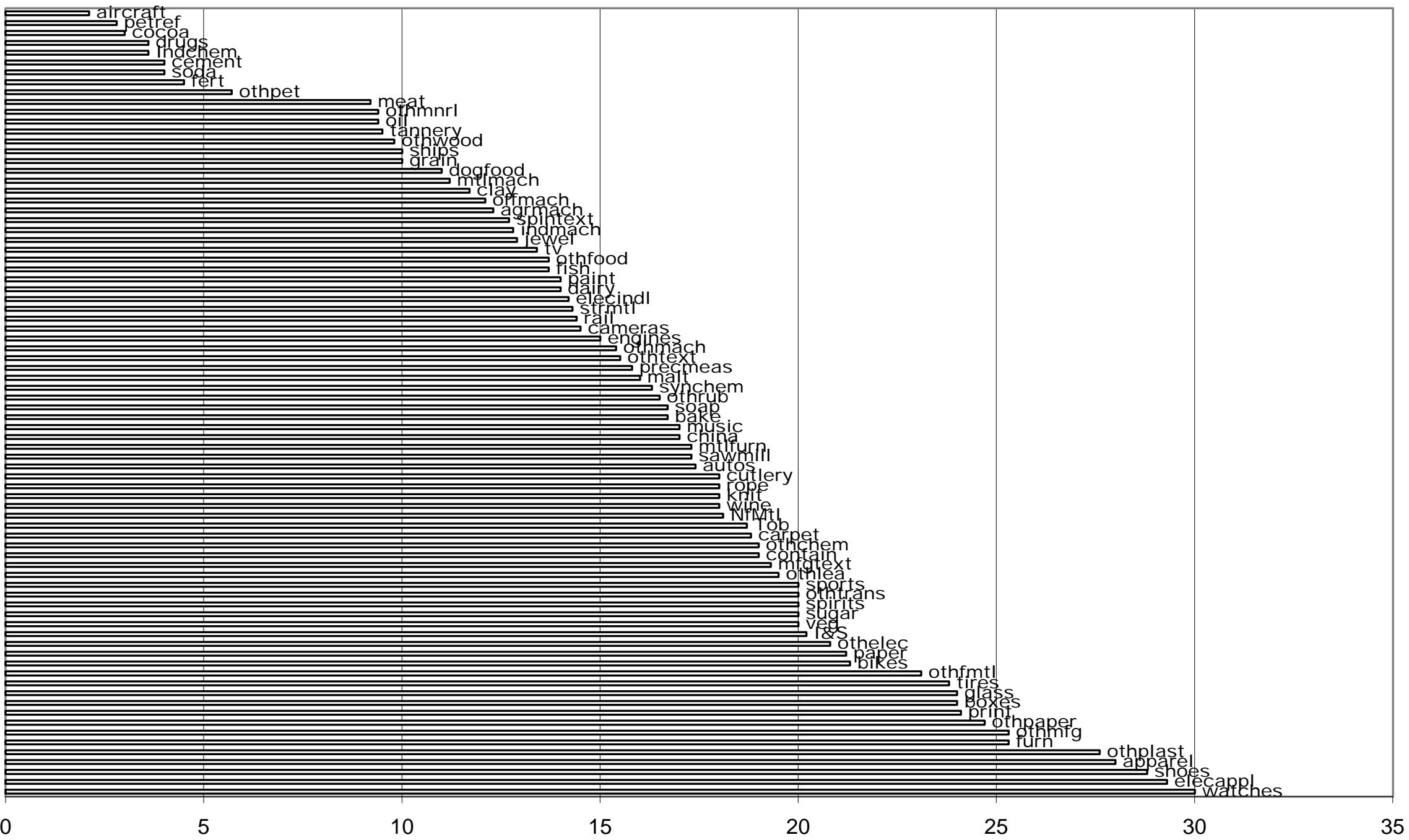

